\title{
ANTICANCER AND ANTIOXIDANT PROPERTIES OF TERPINOLENE IN RAT BRAIN CELLS
}

\author{
Elanur AYDIN ${ }^{1}$, Hasan TÜRKEZ ${ }^{2}$, and Şener TAȘDEMIR ${ }^{3}$ \\ Department of Biology, Faculty of Science, Atatürk University', Department of Molecular Biology and Genetics, \\ Faculty of Science, Erzurum Technical University², Department of Medical Genetics, Ataturk University, \\ Erzurum, Turkey
}

Received in February 2013

CrossChecked in May 2013

Accepted in May 2013

\begin{abstract}
Terpinolene (TPO) is a natural monoterpene present in essential oils of many aromatic plant species. Although various biological activities of TPO have been demonstrated, its neurotoxicity has never been explored. In this in vitro study we investigated TPO's antiproliferative and/or cytotoxic properties using the 3-(4,5-dimethylthiazol-2-yl)-2,5 diphenyltetrazolium bromide (MTT) test, genotoxic damage potential using the single-cell gel electrophoresis (SCGE), and oxidative effects through total antioxidant capacity (TAC) and total oxidative stress (TOS) in cultured primary rat neurons and N2a neuroblastoma cells. Dose-dependent effects of TPO (at $10 \mathrm{mg} \mathrm{L}^{-1}, 25 \mathrm{mg} \mathrm{L}^{-1}, 50 \mathrm{mg} \mathrm{L}^{-1}, 100 \mathrm{mg} \mathrm{L}^{-1}, 200 \mathrm{mg} \mathrm{L}^{-1}$, and $400 \mathrm{mg} \mathrm{L}^{-1}$ ) were tested in both cell types. Significant $(P<0.05)$ decrease in cell proliferation were observed in cultured primary rat neurons starting with the dose of $100 \mathrm{mg} \mathrm{L}^{-1}$ and in $\mathrm{N} 2 \mathrm{a}$ neuroblastoma cells starting with $50 \mathrm{mg} \mathrm{L}^{-1}$. TPO was not genotoxic in either cell type. In addition, TPO treatment at $10 \mathrm{mg} \mathrm{L}^{-1}, 25 \mathrm{mg} \mathrm{L}^{-1}$, and $50 \mathrm{mg} \mathrm{L}^{-1}$ increased TAC in primary rat neurons, but not in N2a cells. However, at concentrations above $50 \mathrm{mg} \mathrm{L}^{-1}$ it increased TOS in both cell types. Our findings clearly demonstrate that TPO is a potent antiproliferative agent for brain tumour cells and may have potential as an anticancer agent, which needs to be further studied.
\end{abstract}

KEY WORDS: antiproliferative agent, comet assay, MTT assay, neurotoxicity, N2a neuroblastoma cell line, oxidative status

Brain cancers (such as astrocytoma, ependymoma, glioblastoma, oligodendroglioma, and neuroblastoma) are among the most devastating tumours in humans and often progress rapidly to the fatal outcome, despite aggressive treatment $(1,2)$. Neuroblastoma (NB) is a paediatric cancer originating in the primitive cells of the sympathetic nervous system and is the most common and deadly solid tumour in childhood $(3,4)$. Being an embryonic tumour, it accounts for $7 \%$ to $10 \%$ of childhood cancers, with an annual incidence of eight per million children under the age of $15(5$, 6). At an advanced stage, the tumour remains aggressive and frequently resistant to chemotherapy in spite of recent advances in multi-modality treatment protocols, with an overall 5-year survival rate of only $30 \%$ to $40 \%$ (7). In adults, the incidence of NB is rather low (8). Random reports in adults with this disease suggest that, at least in some cases, long-term survival may be worse than in younger patients, even with the localised disease, although the course may be longer (9-16).

Oxidative stress has long been confirmed to play a key role in neurodegenerative disorders (17-19). Recent investigations have focused on therapeutic substances capable of reducing the genotoxicity or carcinogenicity of various natural and man-made mutagens. These substances include antibodies, fatty acids, amino acids, minerals, plant extracts, phenolic 
compounds, and boron compounds such as boric acid and borax (20-26).

Essential oils are a diverse group of natural products that are largely composed of terpenes (27). Monoterpenes extracted from vegetables, herbs, spices, and fruits (28) have long been used to flavour food and beverages and to enhance perfumes (29). Terpinolene (TPO, 1-isopropenyl-4-methylcyclohex3 -ene) is a monoterpenic constituent of essential oils of plants such as Melaleuca alternifolia, Melaleuca trichostachya, Manilla elemi, Nectranda elaiophora, and Dacrydium colensoi (30-32). TPO has a broad spectrum of biological activities such as anticancer (33), antioxidant (34), antifungal (35), and larvacidal (36). These important biological effects have raised interest in research of the antiproliferative effects induced by several monoterpenes such as carvacrol and $\alpha$-pinene on human ovarian, hepatocellular, and metastatic breast cancer cells (37, 38). To the best of our knowledge, however, neurotoxic and/or anticancer potentials of TPO in brain cells have never been investigated. Our study was intended to address this gap by evaluating different in vitro biological activities of TPO, including cytotoxic, genotoxic and oxidative effects on primary rat neurons and $\mathrm{N} 2 \mathrm{a}$ neuroblastoma cells.

\section{MATERIALS AND METHODS}

\section{Cell cultures}

This study was conducted at the Atatürk University Medical Experimental Research Center (Erzurum, Turkey). The Ethics Committee of Atatürk University approved the study protocol. All procedures were performed in accordance with the National Institute of Health Principles of Laboratory Animal Care (39). Primary rat neuron cultures were prepared from brains of five newborn male Sprague-Dawley rats. The cerebral cortices were dissociated with Hank's Balanced Salt Solution (HBSS; Sigma-Aldrich ${ }^{\circledR}$, Steinheim, Germany) + Trypsin-EDTA (0.25\% trypsin $+0.02 \%$ EDTA; Sigma-Aldrich $\left.{ }^{\circledR}\right)$, treated with DNAse type 1 (120 units $\mathrm{mL}^{-1}$, Sigma, St Louis ${ }^{\circledR}$, MO, USA) and centrifuged. After having thrown away the supernatant, neurobasal medium and foetal calf serum (PAN Biotech ${ }^{\circledR}$, Germany) were added to the residue. Single cell suspension, which was obtained after physical and chemical decomposition, was divided into $3.5 \mathrm{~mL}$ samples pipetted into 10 flasks coated with poly-D-lysine dissolved in phosphate buffer solution. The flasks were left in the incubator with $5 \% \mathrm{CO}_{2}$ at $37^{\circ} \mathrm{C}$. Fresh medium was added every three days until the cells branched out (40).

The rat brain neuroblastoma cell line N2a is widely used as a model for brain cancer. It was obtained from the FMD Institute, Ankara, Turkey. Prior to the experiments, the cells were thawed and grown in tissue culture flasks as a monolayer in Dulbecco's Modified Eagle's medium, (DMEM; Sigma-Aldrich ${ }^{\circledR}$ ) supplemented with $1 \%$ glutamine, $0.5 \%$ penicillin/ streptomycin (PAN Biotech, Germany) and $10 \%$ foetal bovine serum at $37{ }^{\circ} \mathrm{C}$ in an incubator with $95 \%$ air humidity and $5 \% \mathrm{CO}_{2}$. The cultured cells were trypsinised with Trypsin-EDTA for a maximum of 5 min and seeded with a subcultivation volume ratio of $1: 3$ to $1: 8$.

\section{TPO treatment in vitro}

Cells were incubated at $37^{\circ} \mathrm{C}$ in a humidified $5 \%$ $\mathrm{CO}_{2} / 95 \%$ air mixture and treated for $24 \mathrm{~h}$ with the following TPO $\left(\mathrm{C}_{10} \mathrm{H}_{16}\right.$, CAS No. 586-62-9; Fluka, Sigma-Aldrich ${ }^{\circledR}$ ) concentrations: $10 \mathrm{mg} \mathrm{L}^{-1}, 25 \mathrm{mg} \mathrm{L}^{-1}$, $50 \mathrm{mg} \mathrm{L}^{-1}, 100 \mathrm{mg} \mathrm{L}^{-1}, 200 \mathrm{mg} \mathrm{L}^{-1}$, and $400 \mathrm{mg} \mathrm{L}^{-1}$. The selection of the doses was based on earlier studies (41-44).

\section{MTT bioassay}

The cells were seeded in 48-well plates incubated at $37{ }^{\circ} \mathrm{C}$ in a humidified $5 \% \mathrm{CO}_{2} / 95 \%$ air mixture and treated with TPO as described above. 3-(4,5dimethylthiazol-2-yl)-2,5-diphenyltetrazolium bromide (MTT) substrate solution was used according to the manufacturer's instructions (Cayman Chemical Company, USA). Briefly, MTT was added to the cell cultures for $3 \mathrm{~h}$. The obtained formazan crystals were dissolved in dimethyl sulphoxide (Sigma-Aldrich, Steinheim, Germany), and the plates analysed using a Microquant reader (Bio-Tek Instruments, USA) at the $570 \mathrm{~nm}$ wavelength.

\section{Comet assay}

The comet assay was performed and scored according to slightly modified protocols reported in literature (45-51) using the OxiSelect 96-Well Comet Assay kits (Cell Biolabs ${ }^{\circledR}$, San Diego, CA, USA). Approximately $5 \times 10^{3}$ neuron cells were suspended in $100 \mu \mathrm{L}^{-1}$ of agarose and layered on slides. Gel was covered with cover slips and allowed to solidify at 
$4{ }^{\circ} \mathrm{C}$ for $30 \mathrm{~min}$ to $60 \mathrm{~min}$. The slides were immersed in freshly prepared cold lysing solution and refrigerated overnight. Followed alkali treatment, electrophoresis, and neutralisation. The slides were then fixed and stained using the Vista Green dye. The whole procedure was carried out in dim light. After coding, the slides were analysed using a Nikon Eclipse E600 fluorescence microscope (Japan) at a magnification of 100x. One well-trained observer (Elanur Aydin) performed all scorings. A total of 100 cells per slide were screened. Total damage score for each slide was calculated by multiplying the number of cells assigned to each grade of damage by the numeric value of the grade and by summing up all grades (giving a maximum possible score of 400 , corresponding to 100 cells at grade 4) $(52,53)$.

\section{TAC and TOS analysis}

Total antioxidant capacity (TAC) and total oxidant status (TOS) of cell cultures were analysed using automated commercial kits (Rel Assay Diagnostics ${ }^{\circledR}$, Gaziantep, Turkey). The major advantage of the TAC assay is that it measures the antioxidant capacity of all antioxidants in a biological sample and not just of a single compound (54). In this test, antioxidants in the sample reduce dark blue-green coloured 2,2'azinobis-(3- ethylbenzothiazoline-6-sulphonate radical to its colourless form. The change in absorbance at $660 \mathrm{~nm}$ corresponds to the total antioxidant level in a sample. The assay was calibrated with a stable antioxidant standard solution of vitamin $\mathrm{E}$ analogue, (Trolox-equivalent) (55). The TOS assay used here is based on the oxidation of the ferrous ion-chelator complex to ferric ion $\left(\mathrm{Fe}^{3+}\right)$, which is mediated by oxidants contained in the tested sample. The reaction is further enhanced by other molecules from the reaction medium. The reaction of $\mathrm{Fe}^{3+}$ with chromogen in an acidic medium produces a coloured complex. Its intensity corresponds to the total amount of oxidants in the sample and can be measured spectrophotometrically. The TOS assay was calibrated with hydrogen peroxide (56), and the results are expressed in terms of micromolar hydrogen peroxide equivalent per litre.

\section{Statistical analysis}

The obtained data were analysed using SPSS for Windows version 18.0 statistical software (SPSS Inc., Chicago, IL, USA). Differences between the groups were compared using the one-way analysis of variance (ANOVA) and Duncan's post-hoc test. The significance level was set at $P<0.05$.

\section{RESULTS}

\section{Antiproliferative activity}

The effects of TPO on cultured primary rat neurons and N2a neuroblastoma cells are shown in Figure 1. The addition of TPO at concentrations below $100 \mathrm{mg} \mathrm{L}^{-1}$ for $24 \mathrm{~h}$ did not cause any change in cell viability in primary rat neurons. However, at higher doses, $\left(100,200\right.$, and 400) $\mathrm{mg} \mathrm{L}^{-1}$, it became cytotoxic. In N2a neuroblastoma cells, TPO treatments started to show antiproliferative effects at the concentrations of $50 \mathrm{mg} \mathrm{L}^{-1}$ and above.

\section{Genotoxicity}

In vitro exposure to TPO of either cell type did not result in comet formation, regardless of the dose, indicating the non-genotoxic nature of TPO (Figure 2).

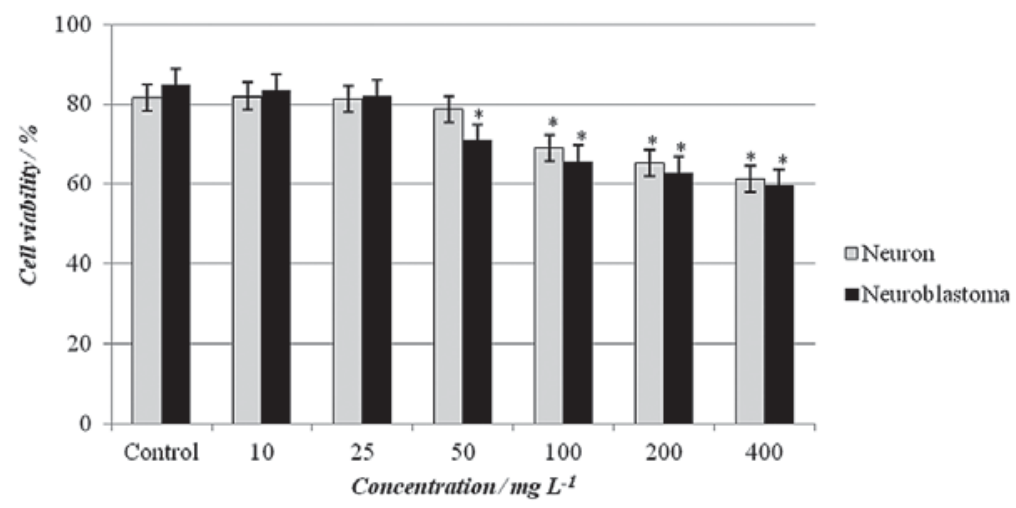

Figure 1 Cytotoxic effects of TPO on cultured primary rat neurons and N2a neuroblastoma cells. $* \mathrm{P}<0.05$ vs. control 


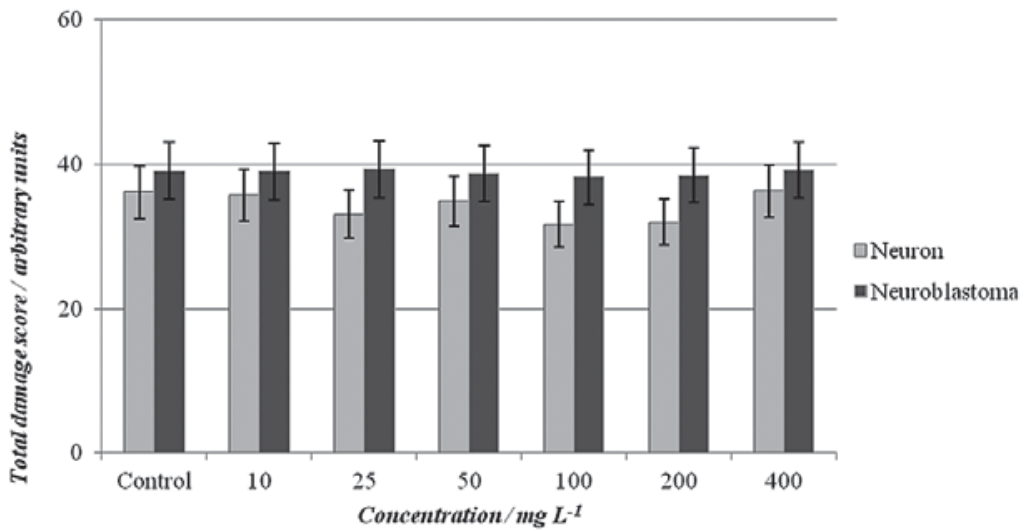

Figure 2 DNA damage induced by varying concentrations of TPO over $72 \mathrm{~h}$

\section{Antioxidant activity}

TPO at the concentrations of $100 \mathrm{mg} \mathrm{L}^{-1}$ and $200 \mathrm{mg} \mathrm{L}^{-1}$ did not affect TAC in primary rat neuron cells, increased it significantly at the concentrations of $(10,25$, and 50$) \mathrm{mg} \mathrm{L}^{-1}$, and decreased it significantly at the highest concentration ( $\left.400 \mathrm{mg} \mathrm{L}^{-1}\right)$ compared to control (Table 1). Similarly, in N2a neuroblastoma cells TPO (at $10 \mathrm{mg} \mathrm{L}^{-1}$ and $25 \mathrm{mg} \mathrm{L}^{-1}$ ) did not change TAC levels, but decreased them significantly at (50, 100, 200, and 400) $\mathrm{mg} \mathrm{L}^{-1}$, compared to control.

On the other hand, TOS levels increased at (100, 200 and 400) $\mathrm{mg} \mathrm{L}^{-1}$ of TPO in primary rat neurons, but had no effect at doses lower than $100 \mathrm{mg} \mathrm{L}^{-1}$. In N2a neuroblastoma cells, TOS significantly rose with TPO concentrations of $50 \mathrm{mg} \mathrm{L}^{-1}$ and above.

\section{DISCUSSION}

Terpinolene and other monoterpenes are lipophilic and highly soluble in blood (57). Inhaled monoterpenes are absorbed almost entirely by the human and animal lungs and then delivered to the liver, where they are completely metabolised by detoxification enzymes (58-61). In addition, Igimi et al. (58) have shown that orally administered limonene, a monoterpene similar to terpinolene, is highly absorbed in the intestine. Although there is no information about TPO metabolites in literature, limonene has been shown to metabolise to oxygenated metabolites in rats and in humans (62). Metabolites of limonene in serum are perillic acid and dihydroperillic acid in rats (63) plus limonene-1,2-diol additionally produced in humans (64). In urine, glycine and glucuronide conjugates of perillic acid and uroterpenol (p-mentha-8,9-diol) have been detected in many limonene-fed mammals (65, 66). Yeruva et al. (67) reported that perillic acid elicited dose-dependent cytotoxicity, induced cell cycle arrest and apoptosis, and increased the expression of bax, p21, and caspase-3 activity in non-small cell lung cancer lines (NSCLC, A549, and H520). In bone

Table 1 Total antioxidant capacity (TAC) and total oxidative stress (TOS) levels in cultured primary rat neurons and N2a neuroblastoma cells exposed to TPO for $24 \mathrm{~h}$

\begin{tabular}{|c|c|c|c|c|}
\hline \multirow{3}{*}{$\begin{array}{l}\text { Treatments with } \\
\text { TPO / mg L }{ }^{-1}\end{array}$} & \multicolumn{2}{|c|}{ Primary rat neurons } & \multicolumn{2}{|c|}{ N2a neuroblastoma cells } \\
\hline & TAC & TOS & TAC & TOS \\
\hline & $\begin{array}{c}\text { (Trolox Equiv. / } \\
\text { mmol L }^{-1} \text { ) }\end{array}$ & $\begin{array}{c}\left(\mathrm{H}_{2} \mathrm{O}_{2} \text { Equiv. / }\right. \\
\left.\text { mmol L }{ }^{-1}\right)\end{array}$ & $\begin{array}{c}\text { (Trolox Equiv. / } \\
\text { mmol L L-1) }\end{array}$ & $\begin{array}{c}\left(\mathrm{H}_{2} \mathrm{O}_{2} \text { Equiv. / }\right. \\
\left.\text { mmol L }^{-1}\right)\end{array}$ \\
\hline Control & $34.5 \pm 5.0$ & $2.1 \pm 0.3$ & $5.9 \pm 0.6$ & $2.8 \pm 0.4$ \\
\hline 10 & $38.2 \pm 5.2^{*}$ & $1.9 \pm 0.3$ & $5.5 \pm 0.7$ & $2.6 \pm 0.3$ \\
\hline 25 & $38.9 \pm 5.1^{*}$ & $2.0 \pm 0.1$ & $6.1 \pm 0.7$ & $2.9 \pm 0.3$ \\
\hline 50 & $39.5 \pm 4.9^{*}$ & $2.1 \pm 0.2$ & $4.9 \pm 0.6^{*}$ & $3.4 \pm 0.5^{*}$ \\
\hline 100 & $34.8 \pm 5.0$ & $2.4 \pm 0.2^{*}$ & $4.5 \pm 0.5^{*}$ & $3.7 \pm 0.6^{*}$ \\
\hline 200 & $34.1 \pm 4.8$ & $2.7 \pm 0.1^{*}$ & $3.9 \pm 0.5^{*}$ & $3.9 \pm 0.4^{*}$ \\
\hline 400 & $27.2 \pm 4.7^{*}$ & $2.9 \pm 0.3^{*}$ & $3.5 \pm 0.6^{*}$ & $4.0 \pm 0.5^{*}$ \\
\hline
\end{tabular}

* $\mathrm{P}<0.05$ vs. control 
marrow of mice exposed to gamma radiation it reduced DNA damage (68).

Because of the widespread use of TPO as a synthetic food flavouring additive or fragrance enhancer in perfumes, some terpene-based air fresheners, and cleaners, the potential for human exposure is high $(69,70)$. Our findings that TPO significantly reduces cell viability in primary rat neurons and N2a neuroblastoma cells are in agreement with earlier reports of the cytotoxic effects of several monoterpenes such as d-limonene (on human normal epithelial prostate PZ-HPV-7 cells), $\alpha$-pinene, myrcene, linalool (on Vero monkey kidney cells), and stylosin (on human foetal fibroblast cells) (71-73). Likewise, Chen et al. (74) reported a strong anticancer effect of $\alpha$-terpinolene against breast and cervical cancer cell lines. In a recent study by Okumura et al. (70), TPO reduced protein expression of AKT1 in K562 human leukemic cells and inhibited cell proliferation. In turn, Matsuo et al. (75) showed that $\alpha$-pinene was able to induce apoptosis, as evidenced by early disruption of the mitochondrial potential, production of reactive oxygen species, and increased caspase- 3 activity in B16F 10 murine melanoma cells. While the exact mechanism of the cytotoxic action of TPO is not known, it is mainly attributed to oxidative stress. In addition to oxidative stress, a number of studies (76-83) have associated the cytotoxicity of plant products with the following mechanisms: proteasome inhibition, topoisomerase inhibition, inhibition of fatty acid synthesis, accumulation of p53, induction of cell cycle arrest, inhibition of phosphatidylinositol 3-kinase, and enhanced expression of c-fos and c-myc.

Our findings also indicate that TPO is not genotoxic to primary rat neurons and N2a neuroblastoma cells. Similarly, Turner et al. (84) reported that limonene was not genotoxic and mutagenic in male Big Blue rats. Slamenova et al. (85) reported that chromosomal aberration assay (CA) in rat primary hepatocytes did not confirm any genotoxic activity of carvacrol and thymol. Gomes-Carneiro et al. (86) also found no mutagen activity of $\beta$-myrcene, $\alpha$-terpinene, and $(+)$ and (-)- $\alpha$-pinene in Salmonella typhimurium TA100, TA98, TA97a, and TA1535 strains. Horvath et al. (87) reported that carvacrol and thymol significantly reduced DNA damage induced by hydrogen peroxide $\left(\mathrm{H}_{2} \mathrm{O}_{2}\right)$ in $\mathrm{K} 562$ cells. Mademtzoglou et al. (88) found no genotoxic effects with $S$-(+)-carvone, while $R$-(-)carvone turned out to be a potent mutagen even at low concentrations in Drosophila melanogaster. In contrast to our findings, National Toxicology Program reported d-carvone-induced changes in sister chromatid exchanges and chromosomal aberrations in Chinese hamster ovary cells (89).

Research into the use of antioxidants in cancer treatment has shown a rapid progress. Antioxidants are extensively studied for their ability to prevent or treat cancer in humans (90). Research has so far showed that monoterpenes such as myrtenal, vallesiachotamine, geraniol, terpinen-4-ol, and linalool exhibit anticancerogenic properties in different experimental models (liver, melanoma, prostate, and non-small cell lung and breast cancers) (91-95). TPO was also suggested to have an important in vitro antitumour effect against K562 human leukemic (70), breast, and cervical cancers (71) and Ehrlich ascites carcinoma cells (96).

Several experimental and epidemiological studies have confirmed the greater or lesser anticancer potentials of a variety of antioxidants (97-99). Furthermore, regular intake of natural antioxidants is associated with reduced risk of cancer (100-102). The antioxidant activity of TPO in our study is similar to the findings by Bourgou et al. (103) in normal human skin fibroblast (WS1) cells. Other recent studies have also demonstrated the antioxidant properties of TPO using 2,2-diphenyl-1-picrylhydrazyl (104), hexanal/ hexanoic acid assay (105), thiobarbituric acid reactive species (96), and beta-carotene agar diffusion methods (34). In our study, however, TPO at $400 \mathrm{mg} \mathrm{L}^{-1}$ significantly lowered TAC, and at concentrations higher than $50 \mathrm{mg} \mathrm{L}^{-1}$ increased TOS in healthy neurons. Furthermore, at $25 \mathrm{mg} \mathrm{L}^{-1}$ it significantly lowered TAC and increased TOS in cancer (neuroblastoma) cells. These findings support earlier findings by Lima et al. (106) that high concentrations of monoterpenoid compounds could lead to neurotoxicity by reducing total glutathione levels and by lactate dehydrogenase leakage of primary rat hepatocytes.

\section{CONCLUSION}

To sum up, TPO was not genotoxic in experimental conditions applied in this study, but it showed antioxidant and antiproliferative properties. These preliminary in vitro findings suggest that TPO is a good and safe natural antioxidant and a potential anticancer agent. However, its dose should be carefully adjusted since it is an ingredient in food and is used 
for pharmaceutical purposes. Future studies, especially on animal models, should further elucidate its possible use in the biotherapy of cancer.

\section{REFERENCES}

1. Maidment SL, Pilkington GJ. Brain Cancers. In: Encyclopaedia of Life Sciences. Nature Publishing Group/MacMillan 2001, (Invited Reference Work for Electronic Publication) doi: 10.1038/npg.els.0001892

2. Clarke MF. Neurobiology: At the root of brain cancer. Nature 2004;432:281-2. doi:10.1038/432281a

3. Maris JM, Matthay KK. Molecular biology of neuroblastoma. J Clin Oncol 1999;17:2264-79. PMID: 10561284

4. Brodeur GM. Neuroblastoma: biological insights into a clinical enigma. Nat Rev Cancer 2003;3:203-16. PMID 12612655

5. Heck JE, Ritz B, Hung RJ, Hashibe M, Boffetta P. The epidemiology of neuroblastoma: a review. Paediatr Perinat Epidemiol 2009;23:125-43. doi: 10.1111/j.13653016.2008.00983.x

6. Mueller WP, Coppenrath E, Pfluger T. Nuclear medicine and multimodality imaging of pediatric neuroblastoma. Pediatr Radiol 2013;43:418-27. doi: 10.1007/s00247-012-2512-1

7. Kang J, Kamal A, Burrows FJ, Evers BM, Chung DH. Inhibition of neuroblastoma xenograft growth by Hsp90 inhibitors. Anticancer Res 2006;26:1903-8. PMID: 16827123

8. Bayrak O, Seckiner I, Erturhan S, Aydin A, Yagci F. Adult intrarenal neuroblastoma presenting as renal cell carcinoma. Can Urol Assoc J 2012;6:E144-6. doi: 10.5489/cuaj.11119

9. Tang CK, Hajdu SI. Neuroblastoma in adolescence and adulthood. NY State J Med 1975;75:1434-8. PMID: 1057061

10. Dosik GM, Rodriguez V, Benjamin RS, Bodey GP. Neuroblastoma in the adult: effective combination chemotherapy. Cancer 1978;41:56-63. PMID: 626943

11. Lopez R, Karakousis C, Rao U. Treatment of adult neuroblastoma. Cancer 1980;45:840-4.

12. Grubb BP, Thant M. Neuroblastoma in an adult. Southern Med J 1984;77:1180-2. PMID: 6484689

13. Aleshire SL, Glick AD, Cruz VE, Bradley CA, Parl FF, Neuroblastoma in adults. Pathologic findings and clinical outcome. Arch Pathol Lab Med 1985;109:352-6. PMID: 3885899

14. Kaye JA, Warhol MJ, Kretschmar C, Landsberg L, Frei E $3^{\text {rd }}$. Neuroblastoma in adults. Three case reports and a review of the literature. Cancer 1986;58:1149-57. PMID: 3731041

15. Allan SG, Cornbleet MA, Carmicael J, Arnott SJ, Smyth JF Adult neuroblastoma: report of three cases and review of the literature. Cancer 1986;57:2419-21. PMID: 3697939

16. Prestidge BR, Donaldson SS. Treatment results among adults with childhood tumors: a 20-year experience. Int J Radiat Oncol Biol Phys 1989;17:507-14. PMID: 2550396

17. Cadet JL, Brannock C. Free radicals and the pathobiology of brain dopamine systems. Neurochem Int 1989;32:117-31. PMID: 9542724

18. Halliwell B. Oxidative stress and neurodegeneration: where are we now? J Neurochem 2006;97:1634-58. doi: 10.1111/ j.1471-4159.2006.03907.x
19. Mecocci P, Mac Garvey U, Beal MF. Oxidative damage to mitochondrial DNA is increased in Alzheimer's disease. Ann Neurol 1994;36:747-51. doi: 10.1002/ana.410360510

20. Türkez H, Geyikoğlu F, Tatar A, Keleş S, Ozkan A. Effects of some boron compounds on peripheral human blood. Z Naturforsch C 2007;62:889-96. PMID: 18274294

21. Turkez H, Geyikoglu F. The effect of laurel leaf extract against toxicity induced by 2,3,7,8-tetrachlorodibenzo-pdioxin in cultured rat hepatocytes. Arh Hig Rada Toksikol 2011;62:309-15. doi: 10.2478/10004-1254-62-2011-2118

22. Turkez H, Aydin E. Anti-genotoxic role of eicosapentaenoic acid against imazalil-induced DNA damage in vitro. Toxicol Ind Health $2012 \mathrm{Feb}$ 8. [Epub ahead of print] doi: $10.1177 / 0748233711433943$

23. Turkez H, Geyikoğlu F, Dirican E, Tatar A. In vitro studies on chemoprotective effect of borax against aflatoxin B1induced genetic damage in human lymphocytes. Cytotechnology 2012;64:607-12. doi: 10.1007/s10616-0129454-1

24. Turkez H, Aydin E. The effects of taurine on permethrin induced cytogenetic and oxidative damage in cultured human lymphocytes. Arh Hig Rada Toksikol 2012;63:27-34. doi: 10.2478/10004-1254-63-2012-2114

25. Shon MY, Choi SD, Kahng GG, Nam SH, Sung NJ. Antimutagenic, antioxidant and free radical scavenging activity of ethyl acetate extracts from white, yellow and red onions. Food Chem Toxicol 2004;42:659-66. PMID: 15019191

26. Sevgiler Y, Karaytug S, Karayakar F. Antioxidative effects of $\mathrm{N}$-acetylcysteine, lipoic acid, taurine, and curcumin in the muscle of Cyprinus carpio L. exposed to cadmium. Arh Hig Rada Toksikol 2011;62:1-9. doi: 10.2478/10004-1254-622011-2082

27. Charles DJ, Simon JE. Comparison of extraction methods for the rapid determination of essential oil content and composition of basil. J Am Soc Hort Sci 1990;115:458-62.

28. Loza-Tavera H. Monoterpenes in essential oils. Biosynthesis and properties. Adv Exp Med Biol 1999;464:49-62. PMID: 10335385

29. Carnesecchi S, Schneider Y, Ceraline J, Duranton B, Gosse F, Seiler N, Raul F. Geraniol, a component of plant essential oils, inhibits growth and polyamine biosynthesis in human colon cancer cells. J Pharmacol Exp Ther 2001;298:197-200. PMID: 11408542

30. Southwell IA, Stiff IA, Brophy JJ. Terpinolene varieties of Melaleuca. J Essent Oil Res 1992;4:363-7. doi: 10.1080/10 412905.1992.9698086

31. Burdock GA. Fenaroli's Hanbook of Flavor Ingredients: Adapted from the Italian Language Works of Giovanni Fenaroli. $3^{\text {rd }}$ ed. Boca Raton: CRC Press; 1995.

32. Brauss MS, Linforth RST, Cayeux I, Harvey B, Taylor AJ. Altering the fat content affects flavor release in a model yogurt system. J Agric Food Chem 1999;47:2055-9. PMID: 10552495

33. Harada T, Harada E, Sakamoto R, Ashitani T, Fujita K, Kuroda K. Regio- and substrate-specific oxidative metabolism of terpinolene by cytochrome P450 monooxygenases in Cupressus lusitanica cultured cells. Am J Plant Sci 2012;3:268-75. doi: 10.4236/ajps.2012.32032

34. Dorman HJD, Figueiredo AC, Barroso JG, Deans SG. In vitro evaluation of antioxidant activity of essential oils and their components. Flavour Fragr J 2000;15:12-6. 
35. Hammer KA, Carson CF, Riley TV. Antifungal effects of Melaleuca alternifolia (tea tree) oil and its components on Candida albicans, Candida glabrata and Saccharomyces cerevisiae. J Antimicrob Chemother 2004;53:1081-5. doi: 10.1093/jac/dkh243

36. Conti B, Benelli G, Flamini G, Cioni PL, Profeti R, Ceccarini L, Macchia M, Canale A. Larvicidal and repellent activity of Hyptis suaveolens (Lamiaceae) essential oil against the mosquito Aedes albopictus Skuse (Diptera: Culicidae) Parasitol Res 2012;110:2013-21. doi: 10.1007/s00436-0112730-8

37. Arunasree KM. Anti-proliferative effects of carvacrol on a human metastatic breast cancer cell line, MDA-MB 231 Phytomedicine 2010;17:581-8. doi: 10.1016/j. phymed.2009.12.008

38. Wang W, Li N, Luo M, Zu Y, Efferth T. Antibacterial activity and anticancer activity of Rosmarinus officinalis $\mathrm{L}$. essential oil compared to that of its main components. Molecules 2012;17:2704-13. doi: 10.3390/molecules17032704

39. Anonymous. National Institute of Health, Principles of Laboratory Animal Care, USA. 1985;23:1-112.

40. Daikhin Y, Yudkoff M. Compartmentation of brain glutamate metabolism in neurons and glia. J Nutr 2000;130(4S Suppl):1026S-31S. PMID: 10736375

41. Zhou JY, Tang FD, Mao GG, Bian RL. Effect of alpha-pinene on nuclear translocation of NF-kappa B in THP-1 cells. Acta Pharmacol Sin 2004;25:480-4. PMID: 15066217

42. Yu Z, Wang W, Xu L, Dong J, Jing Y. d-Limonene and dcarvone induce apoptosis in HL-60 cells through activation of caspase-8. Asian J Trad Med 2008;3:134-43.

43. Buyukleyla M, Rencuzogullari E. The effects of thymol on sister chromatid exchange, chromosome aberration and micronucleus in human lymphocytes. Ecotoxicol Environ Saf 2009;72:943-7. doi: 10.1016/j.ecoenv.2008.10.005

44. Aristatile B, Al-Numair KS, Al-Assaf AH, Pugalendi KV. Pharmacological effect of carvacrol on D: -galactosamineinduced mitochondrial enzymes and DNA damage by singlecell gel electrophoresis J Nat Med 2011;65:568-77. doi: 10.1007/s11418-011-0544-8

45. Singh DK, Lippman SM. Cancer chemoprevention part 1: retinoids and carotenoids and other classic antioxidants. Oncology 1998;12:1643-60. PMID: 9834941

46. Kizilian N, Wilkins RC, Reinhardt P, Ferrarotto C, McLean JR, McNamee JP. Silver stained comet assay for detection of apoptosis. Biotechniques 1999;27:926-30. PMID: 10572638

47. Tice RR, Agurell E, Anderson D. Single cell gel/comet assay: guidelines for in vitro and in vivo genetic toxicology testing. Environ Mol Mutagen 2000;35:206-21. PMID: 10737956

48. Saleha Banu B, Dana Devi K, Mahboob M. In vivo genotoxic effect of zinc sulfate in mouse peripheral blood leukocytes using comet assay. Drug Chem Toxicol 2000;24:63-73. doi: 10.1081/DCT-100103086

49. Heaton PR, Ransley R, Charlton CJ. Application of single-cell gel electrophoresis (comet) assay for assessing levels of DNA damage in canine and feline leukocytes. J Nutr 2002;132(6 Suppl 2):1598S-603S. PMID: 12042468

50. Das GP, Shaik AP, Jamil K. Cytotoxicity and genotoxicity induced by the pesticide profenofos on cultured human peripheral blood lymphocytes. Drug Chem Toxicol 2006;29:313-22. doi: 10.1080/01480540600653093

51. Turkez H. The role of ascorbic acid on titanium dioxideinduced genetic damage assessed by the comet assay and cytogenetic tests. Exp Toxicol Pathol 2011;63:453-7. doi: 10.1016/j.etp.2010.03.004

52. Todoriki S, Hasan M, Miyanoshita A, Imamura T, Hayashi T. Assessment of electron beam-induced DNA damage in larvae of chestnut weevil, Curculio sikkimensis (Heller) (Coleoptera: Curculionidae) using comet assay. Radiat Physic Chem 75;2006:292-6. doi: 10.1016/j. radphyschem.2005.08.001

53. Aydın E, Türkez H, Keleș MS. The effect of carvacrol on healthy neurons and N2a cancer cells: some biochemical, anticancerogenicity and genotoxicity studies. Cytotechnology 2013; (in press) doi: 10.1007/s10616-013-9547-5.

54. Kusano C, Ferrari B. Total antioxidant capacity: a biomarker in biomedical and nutritional studies. J Cell Mol Biol 2008; 7:1-15.

55. Erel O. A novel automated method to measure total antioxidant response against potent free radical reactions. Clin Biochem 2004;37:112-9. doi: 10.1016/j. clinbiochem.2003.10.014

56. Erel O. A new automated colorimetric method for measuring total oxidant status. Clin Biochem 2005;38:1103-11. doi: 10.1016/j.clinbiochem.2005.08.008

57. Falk AA, Hagberg MT, Lof AE, Wigaeus-Hjelm EM, Zhiping W. Uptake, distribution and elimination of alpha-pinene in man after exposure by inhalation. Scand J Work Environ Health 1990;16:372-8. doi: 10.5271/sjweh.1771

58. Igimi H, Nishimura M. Studies on the metabolism of d-limonene (p-Mentha-1,8-diene). I. The absorption, distribution, and excretion of d-limonene in rats. Xenobiotica 1974;4:77-84. doi: 10.3109/00498257409049347

59. Foley WJ, Lassak EV, Brophy J. Digestion and absorption of Eucalyptus essential oils in greater glider (Petauroides volans) and brushtail possums (Trichosurus vulpecula). J Chem Ecol 1987;13:2115-30. doi: 10.1007/BF01012875

60. Boyle R, McLean S, Foley WJ, Davies NW. Comparative metabolism of dietary terpene, p-cymene, in generalist and specialist folivorous marsupials. J Chem Ecol 1999;25:210927. doi: 10.1023/A:1021092908058

61. Boyle R, McLean S, Davies NW. Biotransformation of 1,8-cineole in the brushtail possum (Trichosurus vulpecula). Xenobiotica 2000;30:915-32. PMID: 11055269

62. Crowell PL. Prevention and therapy of cancer by dietary monoterpenes. J Nutr 1999;129:775S-8S. PMID: 10082788

63. Crowell PL, Lin S, Vedejs E, Gould MN. Identification of metabolites of the antitumor agent d-limonene capable of inhibiting protein isoprenylation and cell growth. Cancer Chemother Pharmacol 1992;31:205-12. doi: 10.1007/ BF00685549

64. Crowell PL, Ren Z, Lin S, Vedejs E, Gould MN. Structureactivity relationships among monoterpene inhibitors of protein isoprenylation and cell proliferation. Biochem Pharmacol 1994;47:1405-15. doi: 10.1016/00062952(94)90341-7

65. Kodama R, Yano T, Furukawa K, Noda K, Ide H. Studies on the metabolism of d-limonene (p-mentha-1,8-diene). IV: Isolation and characterization of new metabolites and species differences in metabolism. Xenobiotica 1976;6:377-89. doi: 10.3109/00498257609151649

66. Regan JW, Bjeldanes LF. Metabolism of (+)-limonene in rats. J Agric Food Chem 1976;24:377-80. doi: 10.1021/ jf60204a031

67. Yeruva L, Pierre KJ, Elegbede A, Wang RC, Carper SW. Perillyl alcohol and perillic acid induced cell cycle arrest and 
apoptosis in non small cell lung cancer cells. Cancer Letters 2007;257:216-26. doi: 10.1016/j.canlet.2007.07.020

68. Pratheeshkumar P, Raphael TJ, Kuttan G. Protective role of perillic acid against radiation-induced oxidative stress, cytokine profile, DNA damage, and intestinal toxicity in mice. J Environ Pathol Toxicol Oncol 2010;29:199-212. PMID: 21303327

69. Ma Y, Marston G. Formation of organic acids from the gasphase ozonolysis of terpinolene. Phys Chem Chem Phys 2009;11:4198-209. doi: 10.1039/B818789D

70. Okumura N, Yoshida H, Nishimura Y, Kitagishi Y, Matsuda S. Terpinolene, a component of herbal sage, downregulates AKT1 expressionin K562 cells. Oncol Lett 2012;3:321-4. doi: 10.3892/ol.2011.491

71. Silva SL, Figueiredo PM, Yano T. Cytotoxic evaluation of essential oil from Zanthoxylum rhoifolium Lam. leaves. Acta Amaz 2007;37:281-6. doi: 10.1590/S004459672007000200015

72. Rabi T, Bishayee A. d-Limonene sensitizes docetaxel-induced cytotoxicity in human prostate cancer cells: Generation of reactive oxygen species and induction of apoptosis. J Carcinog 2009;8:9. doi: 10.4103/1477-3163.51368

73. Rassouli FB, Matin MM, Iranshahi M, Bahrami AR. Investigating the cytotoxic and apoptosis inducing effects of monoterpenoid stylosin in vitro. Fitoterapia 2011;82:742-9. doi: 10.1016/j.fitote.2011.03.005

74. Chen F, Kim HJ, Wang X, Wu C, Chung HY, Jin Z. Evaluation of antioxidant and antiproliferative activities of tea tree (Melaleuca alternifolia) oil. In: IFT Annual Meeting; 12-16 July 2004. Las Vegas, Nevada, USA.

75. Matsuo AL, Figueiredo CR, Arruda DC, Pereira FV, Scutti JAB, Massaoka MH, Travassos LR, Sartorelli P, Lago JHG $\alpha$-Pinene isolated from Schinus terebinthifolius Raddi (Anacardiaceae) induces apoptosis and confers antimetastatic protection in a melanoma model. Biochem Biophys Res Commun 2011;411:449-54. doi: 10.1016/j. bbrc.2011.06.176

76. Constantinou A, Mehta R, Runyan C, Rao K, Vaughan A, Moon R. Flavonoids as DNA topoisomerase antagonists and poisons: structure-activity relationships. J Nat Prod 1995;58:217-25. doi: 10.1021/np50116a009

77. Lepley DM, Li B, Birt DF, Pelling JC. The chemopreventive flavonoid apigenin induces $\mathrm{G} 2 / \mathrm{M}$ arrest in keratinocytes. Carcinogenesis 1996;17:2367-75. PMID: 8968050

78. Plaumann B, Fritsche M, Rimpler H, Brandner G, Hess RD. Flavonoids activate wild-type p53. Oncogene 1996;13:160514. PMID: 8895505

79. Agullo G, Gamet-Payrastre L, Manenti S, Viala C, Remesy C, Chap H, Payrastre B. Relationship between flavonoid structure and inhibition of phosphatidylinositol 3-kinase: a comparison with tyrosine kinase and protein kinase C inhibition. Biochem Pharmacol 1997;53:1649-57. doi: 10.1016/S0006-2952(97)82453-7

80. Chen ZP, Schell JB, Ho CT, Chen KY. Green tea epigallocatechin gallate shows a pronounced growth inhibitory effect on cancerous cells but not on their normal counterparts. Cancer Lett 1998;129:173-9. doi: 10.1016/ S0304-3835(98)00108-6

81. Kazi A, Wang Z, Kumar N, Falsetti SC, Chan TH, Dou QP. Structure activity relationships of synthetic analogs of (-) epigallocatechin-3-gallate as proteasome inhibitors. Anticancer Res 2004;24:943-54. PMID: 15161048
82. Chen D, Daniel KG, Chen MS, Kuhn DJ, Landis-Piwowar KR, Dou QP. Dietary flavonoids as proteasome inhibitors and apoptosis inducers in human leukemia cells. Biochem Pharmacol 2005;69:1421-32. doi: 10.1016/j. bcp.2005.02.022

83. Brusselmans K, Vrolix R, Verhoeven G, Swinnen JV. Induction of cancer cell apoptosis by flavonoids is associated with their ability to inhibit fatty acid synthase activity. J Biol Chem 2005;280:5636-45. doi: 10.1074/jbc.M408177200

84. Turner SD, Tinwell H, Piegorsch W, Schmezer P, Ashby J. The male rat carcinogens limonene and sodium saccharin are not mutagenic to male Big Blue rats. Mutagenesis 2001;16:329-32. doi: doi: 10.1093/mutage/16.4.329

85. Slamenová D, Horváthová E, Sramková M, Marsálková L. DNA-protective effects of two components of essential plant oils carvacrol and thymol on mammalian cells cultured in vitro. Neoplasma 2007;54:108-12. PMID: 17319782

86. Gomes-Carneiro MR, Viana ME, Felzenszwalb I, Paumgartten FJ. Evaluation of beta-myrcene, alpha-terpinene and (+)- and (-)-alpha-pinene in the Salmonella/microsome assay. Food Chem Toxicol 2005;43:247-52. doi: 10.1016/j. fct.2004.09.011

87. Horváth GY, Kocsis B, Botz L, Németh J, Hungarian LGy. Antibacterial activity of Thymus phenols by direct bioautography. Acta Biol Szegediensis 2002:46(3-4):1456.

88. Mademtzoglou D, Akmoutsou P, Kounatidis I, Franzios G, Drosopoulou E, Vokou D, Mavragani-Tsipidou P. Applying the Drosophila wing spot test to assess the genotoxic impact of 10 essential oil constituents used as flavouring agents or cosmetic ingredients. Flavour Frag J 2011;26:447-51. doi: 10.1002/ffj.2081

89. National Toxicology Program. NTP toxicology and carcinogenesis studies of d-carvone (CAS No. 2244-16-8) in B6C3F1mice (gavage studies). Natl Toxicol Program Tech Rep 1990;381:1-113. PMID: 12692655

90. Singh NP, McCoy MT, Tice RR. A simple technique for quantitation of low level of DNA damage in individual cells. Exp Cell Res 1998;17:184-91. doi: 10.1016/00144827(88)90265-0

91. Ravizza R, Gariboldi MB, Molteni R, Monti E. Linalool, a plant-derived monoterpene alcohol, reverses doxorubicin resistance in human breast adenocarcinoma cells. Oncol Rep 2008;20:625-30. PMID: 18695915

92. Hari Babu L, Perumal S, Balasubramanian MP. Myrtenal, a natural monoterpene, down-regulates TNF- $\alpha$ expression and suppresses carcinogen-induced hepatocellular carcinoma in rats. Mol Cell Biochem 2012;369:183-93. doi: 10.1007/ s11010-012-1381-0

93. Soares PR, de Oliveira PL, de Oliveira CM, Kato L, Guillo LA. In vitro antiproliferative effects of the indole alkaloid vallesiachotamine on human melanoma cells. Arch Pharm Res 2012;35:565-71. doi: 10.1007/s12272-012-0320-7

94. Kim SH, Park EJ, Lee CR, Chun JN, Cho NH, Kim IG, Lee S, Kim TW, Park HH, So I, Jeon JH. Geraniol induces cooperative interaction of apoptosis and autophagy to elicit cell death in PC-3 prostate cancer cells. Int J Oncol 2012;40:1683-90. doi: 10.3892/ijo.2011.1318

95. Wu CS, Chen YJ, Chen JJ, Shieh JJ, Huang CH, Lin PS, Chang GC, Chang JT, Lin CC. Terpinen-4-ol induces apoptosis in human nonsmall cell lung cancer in vitro and in 
vivo. Evid Based Complement Alternat Med 2012;2012:818261. doi: 10.1155/2012/818261

96. Mohamed AA, El-Emary GA, Ali HF. Influence of some citrus essential oils on cell viability, glutathione-S-transferase and lipid peroxidation in Ehrlich ascites carcinoma cells. J Am Sci 2010;6:820-6.

97. Ohgami Y, Elstad CA, Chung E, Shirachi DY, Quock RM, Lai HC. Effect of hyperbaric oxygen on the anticancer effect of artemisinin on molt-4 human leukemia cells. Anticancer Res 2010;30:4467-70. PMID: 21115894

98. Zhou D, Papayannis I, Mackenzie GG, Alston N, Ouyang N, Huang L, Nie T, Wong CC, Rigas B. The anticancer effect of phospho-tyrosol-indomethacin (MPI 621), a novel phospho-derivative of indomethacin: In vitro and in vivo studies. Carcinogenesis 2013;34:943-51. doi: 10.1093/carcin/ bgs394)

99. Kwan HY, Yang Z, Fong WF, Hu YM, Yu ZL, Hsiao WLW. The anticancer effect of oridonin is mediated by fatty acid synthase suppression in human colorectal cancer cells. J Gastroenterol 2013;48:182-92. doi: 10.1007/s00535-0120612-1

100. Cai Y, Luo Q, Sun M, Corke H. Antioxidant activity and phenolic compounds of 112 traditional Chinese medicinal plants associated with anticancer. Life Sci 2004;74:2157-84. doi: $10.1016 /$ j.lfs.2003.09.047
101. Matés JM, Segura JA, Alonso FJ, Márquez J Natural antioxidants: therapeutic prospects for cancer and neurological diseases. Mini-Rev Med Chem 2009;9:1202-14. doi: 10.21 74/138955709789055180

102. Singh A, Jain A, Sarma B K, Jha A, Singh HB. Natural antioxidants and their role in cancer prevention. In: Shankar S, Srivastava RK, editors. Nutrition, diet and cancer. Berlin: Springer; 2012. p. 563-83.

103. Bourgou S, Pichette A, Lavoie S, Marzouk B, Legault J. Terpenoids isolated from Tunisian Nigella sativa L. essential oil with antioxidant activity and the ability to inhibit nitric oxide production. Flavour Frag J 2012;27:69-74. doi: $10.1002 / \mathrm{ffj} .2085$

104. Ruberto G, Baratta MT. Anticancer, antioxidant and antimicrobial activities of the essential oil of Lycopus lucidus Turcz. var. hirtus Regel. Food Chem 2000;69:167-74. doi: 10.1016/j.foodchem.2010.12.027

105. Kim HJ, Chen F, Wu C, Wang X, Chung HY, Jin Z. Evaluation of antioxidant activity of Australian tea tree (Melaleuca alternifolia) oil and its components. J Agric Food Chem 2004:52:2849-54. doi: 10.1021/jf035377d

106. Lima CF, Carvalho F, Fernandes E, Bastos ML, SantosGomes PC, Fernandes-Ferreira M, Pereira-Wilson C. Evaluation of toxic/protective effects of the essential oil of Salvia officinalis on freshlyisolated rat hepatocytes. Toxicol In Vitro 2004;18:457-65. doi: 10.1016/j.tiv.2004.01.001 
Sažetak

\section{PROTUTUMORSKA I ANTIOKSIDATIVNA SVOJSTVA TERPINOLENA U MOŽDANIH STANICA ŠTAKORA}

Terpinolen (TPO) prirodni je monoterpen prisutan u esencijalnim uljima mnogih aromatskih biljaka. Premda su otprije poznate razne biološke aktivnosti TPO-a, dosad nije ispitana njegova neurotoksičnost. Svrha je ovog istraživanja in vitro bila utvrditi antiproliferacijska i/ili citotoksična svojstva TPO-a pomoću testa 3-(4,5-dimetiltiazol-2-yl)-2,5 difeniltetrazolijeva bromida (MTT), njegov genotoksični potencijal pomoću komet-testa te oksidativno djelovanje kroz ukupni antioksidativni kapacitet i ukupni oksidativni stres u uzgojenim primarnim neuronima štakora $\mathrm{i} \mathrm{N}_{2}$ a stanicama neuroblastoma. $\mathrm{U}$ objema staničnim linijama ispitani su učinci TPO-a u skladu sa sljedećim dozama: $10 \mathrm{mg} \mathrm{L}^{-1}, 25 \mathrm{mg} \mathrm{L}^{-1}, 50 \mathrm{mg} \mathrm{L}^{-1}, 100 \mathrm{mg}$ $\mathrm{L}^{-1}, 200 \mathrm{mg} \mathrm{L}^{-1}$ i $400 \mathrm{mg} \mathrm{L}^{-1}$. Značajni $(p<0.05)$ pad stanične proliferacije u primarnim neuronima štakora zamijećen je pri dozama od $100 \mathrm{mg} \mathrm{L}^{-1}$ naviše, a u N $\mathrm{N}_{2}$ a stanicama neuroblastoma pri dozama od $50 \mathrm{mg}$ $\mathrm{L}^{-1}$ naviše. Niti u jednoj staničnoj liniji TPO se nije pokazao genotoksičnim. Usto se primjenom TPO-a pri dozama od $10 \mathrm{mg} \mathrm{L}^{-1}, 25 \mathrm{mg} \mathrm{L}^{-1}$ i $50 \mathrm{mg} \mathrm{L}^{-1}$ povećao ukupni antioksidativni kapacitet primarnih štakorskih neurona, ali je takvo djelovanje izostalo $\mathrm{u} \mathrm{N}_{2}$ a stanica. Međutim, pri koncentracijama višim od $50 \mathrm{mg} \mathrm{L}^{-1} \mathrm{TPO}$ je povećao ukupni oksidativni stres u objema staničnim linijama. Naši rezultati nedvojbeno pokazuju da je TPO snažan antiproliferacijski agens u tumorskih stanica mozga, a njegovu potencijalnu ulogu kao protutumorskog lijeka trebalo bi dalje istraživati.

KLJUČNE RIJEČI: antiproliferacijski agens, komet test, MTT, neurotoksičnost, $N_{2}$ a stanice, neuroblastom, oksidacijski status

\section{CORRESPONDING AUTHOR:}

Dr Elanur Aydin

Department of Biology, Faculty of Science,

Atatürk University

25240, Erzurum, Turkey

E-mail: elanuraydinn@mail.com 